\title{
Repressiot Venäjän historiapolitiikassa 2008-2018
}

Artikkeli käsittelee Venäjällä vuosina 2008-2018 tehtyä poliittisten repressioiden historiapolitiikkaa. Tarkoitus on tarkastella sitä, miten Venäjän valtio on presidentillisissä kannanotoissaan käyttänyt repressioiden muistoa poliittisiin ja yhteiskunnallisiin tarkoituksiin, ja sitä, miten valtiojohtoinen historiapoliittinen toiminta on heijastunut kansalaisjärjestö Memorialin ja Venäjän ortodoksisen kirkon poliittisten repressioiden historiapolitiikkoihin. Tutkimuksen aineisto koostuu Venäjän presidenttien tekemistä historiapoliittisista kannanotoista ja poliittisten repressioiden historiapolitiikkaa käsittelevistä, verkossa julkaistuista uutisteksteistä. Repressiohistorian aktiivisen hyödyntämisen avulla pyritään edistämään presidentinhallinnolle tärkeitä arvoja. Tällaisia ovat esimerkiksi vahva valtio, kansallinen yhtenäisyys ja nykyisen hallinnon legitimiteetin tukeminen. Huomionarvoista on, että valtiolla näyttäisi olevan voimistuva pyrkimys rajoittaa ja kontrolloida itsestään riippumatonta repressioiden historiapolitiikkaa. Tämä näyttäisi liittyvän kiinteästi samanaikaiseen yhteiskunnan autoritaaristumiskehitykseen.

Historia on Venäjällä merkittävä poliittisen ja sosiaalisen vallankäytön väline. Tämä on korostunut entisestään 2010-luvun aikana, kun Venäjän poliittinen ilmapiiri on kiristynyt ja hallinto ja päätöksenteko ovat muuttuneet aiempaa autoritaarisempaan suuntaan. Tähän liittyvät olennaisesti samanaikainen poliittisen pluralismin vähentyminen, valtion autoritaarisuuden vahvistuminen ja kansalaisyhteiskunnan toiminnan ja julkisen keskustelun edellytyksien heikkeneminen. Kun näkemys tulevaisuudesta on muuttunut epämääräiseksi, on venäläinen yhteiskunta alkanut kääntyä enenevässä määrin sisäänpäin ja suuntautua 
tulevaisuuden sijaan menneisyyteen ja sen tarkasteluun. Esimerkiksi kansalaisjärjestö Volnoje istoriť̌seskoje obštšestvo on esittänyt historian roolin laajentuneen Venäjällä silkasta yhteiskunnan lujittamisen välineestä suoranaiseksi poliittiseksi ja aatteelliseksi ideologian korvikkeeksi, jonka tarkoitus olisi korvata avoin ajankohtaiskeskustelu nykyisyydestä ja tulevaisuudesta (Volnoje istoritšeskoje obštšestvo 2017, 3-4). Erityisen mielenkiintoista on kuitenkin se, miten historian vaietumpia ilmiöitä ja suoranaisia kipupisteitä on käsitelty ja käsitellään osana venäläistä yhteiskuntaa. Eräs näistä menneisyyden kipupisteistä ovat Neuvostoliiton aikaiset poliittiset repressiot.

Tässä artikkelissa tarkastelen laadullisen sisällönanalyysin avulla Venäjällä vuosina 2008-2018 tehtyä Neuvostoliiton poliittisten repressioiden valtiollista historiapolitiikkaa eli sitä, miten repressioiden muistoa on käytetty ja käytetään poliittisiin ja yhteiskunnallisiin tarkoituksiin. Tarkastelen Dmitri Medvedevin ja Vladimir Putinin presidenttikausillaan (2008-2012 ja 2012-2018) aiheesta tekemiä historiapoliittisia kannanottoja, ja valtiojohtoisen historiapoliittisen toiminnan heijastumista kansalaisjärjestö Memorialin ja Venäjän ortodoksisen kirkon poliittisista repressioista tuottamiin historiapolitiikkoihin.

Artikkelissa käytetään poliittisten repressioiden käsitettä kuvaamaan kaikkea Neuvostoliiton yhteiskuntajärjestelmään sisältynyttä poliittista väkivaltaa. Arkikielessä tästä väkivallasta on käytetty usein nimitystä "Gulag", mutta se ei ota riittävän kattavasti huomioon Neuvostoliitossa esiintyneen poliittisen väkivallan moninaisuutta ja ajallista laajuutta. Esimerkiksi Michael Jakobson kuvasi nimityksen "GULAG" tarkoittaneen ainoastaan lyhennettä leiriasiain päähallinto -nimiselle hallintoelimelle, josta tuli oma kokonaisuutensa vasta vuonna 1930 ja joka alkoi pian omalta osaltaan hallinnoida ojennus- ja työleirejä (Jakobson 2015, 119).

Alueellisesti rajaan artikkelini käsittelemään poliittisten repressioiden historiapolitiikkaa vain nykyisen Venäjän federaation alueella. Tällainen rajaus on erityisen kiinnostava siksi, että Neuvostoliiton hajoamisen jälkeisen Venäjän historiapolitiikan lähtökohdat erosivat suhteessa muista neuvostotasavalloista, etenkin mitä tuli syyllisyyskysymyksen käsittelyyn. Repressioita analysoitaessa tulee huomioida, että kyse on ennen kaikkea valtion sisäisen väkivallan perinnön käsittelystä. Tämä tekee niiden muiston käsittelystä erilaista kuin monen muun traumaattisen historian ajanjakson julkisesta käsittelystä. Vankileirijärjestelmän toiminta perustui valtion kansalaisiinsa ja kansalaisten toisiinsa kohdistamalle sisäiselle väkivallalle. Tämän vuoksi sitä voi pitää silloisen yhteiskuntajärjestelmän sisäänrakennettuna osana (ks. esim. Anstett 2011, Ulturgaševa 2015, 15-17; Volk 2009, 56-57).

Ajallisesti tarkastelu keskittyy vuosiin 2008-2018. Kyseinen ajanjakso osoittautunee tärkeäksi myöhemmän poliittisista repressioista käydyn keskustelun ja sen kehityksen kannalta: siihen ovat tähän mennessä sisältyneet toisaalta Venäjän valtion oman poliittisten repressioiden historiapolitiikan käynnistyminen vuoden 2015 valtiollisen säädöksen nro. 1561 myötä, toisaalta samanaikaiset Memorialin ja ortodoksisen kirkon historiapolitiikkoihin kohdistuvat rajoitus- ja kontrollointiyritykset (Ks. Pravitelstvo Rossijskoi federatsii 2015, Vedomosti 2015, Koržova \& Muhametšina 2018). Jälkimmäisten taustalla näyttävät lähes poikkeuksetta olleen joko Venäjän valtion edustajat tai muut sille lojaalit tahot. On huomioitava, että etenkin Venäjän nykyisessä yhteiskunnallisessa tilanteessa on valtiojohtoisella, vasta kehittyvällä historiapolitiikalla laajimmat mahdollisuudet ja parhaat edellytykset luoda haluamansalaista poliittisten repressioiden historiapolitiikkaa, ja sitä myötä laajimmat mahdollisuudet vaikuttaa yhteiskunnan historiakäsitysten muotoutumiseen. ${ }^{1}$ Nähtäväksi jää, missä määrin poliittisista repressioista tulee valtion uusi historiapoliittisen vallankäytön väline (samaan tapaan kuin esimerkiksi "suuresta isänmaallisesta sodasta", ks. Wood 2011). 


\section{Historiapolitiikan ja historiakulttuurin käsitteistä}

Valtiotieteen tohtori Pilvi Torstin mukaan historiapolitiikalla tarkoitetaan sellaista tietoisesti tapahtuvaa historian poliittista käyttöä ja tulkintaa, jonka avulla pyritään saavuttamaan tiettyjä poliittisia ja yhteiskunnallisia tavoitteita. Käsite on saksalaisperäinen: esimerkiksi filosofi Jürgen Habermas puhui historiapolitiikasta 1980-luvun jälkipuoliskolla kritisoidessaan niitä konservatiiveina pitämiään saksalaisia historioitsijoita, jotka hänen mukaansa käyttivät hyväkseen ammatillista asemaansa tulkitakseen Saksan historiaa aikalaispolitiikalle suotuisalla tavalla. (Torsti 2008a, 62.) Esimerkkejä historiapolitiikan eri muodoista ovat koulujen historianopetus, juridisten toimijoiden päätökset, yhteiskunnallisten tahojen puheet ja kommentit sekä julkinen historiakulttuuri (ibid, 62-65). Julkisella historiakulttuurilla tarkoitetaan julkisessa tilassa tapahtuvaa historian poliittista käyttöä. Esimerkkejä tästä ovat erilaiset muistomerkit, katujen nimet, museot ja muistopäivät. Myös tämän kaltaisten historiakulttuurien muotojen puuttuminen, poistaminen, poistaminen ja kieltäminen ovat historian poliittista käyttöä (ibid, 63.) Historiapolitiikan taustalla voi erottaa sisäpoliittisia, ulkopoliittisia ja yleisesti hyväksyttyihin perusarvoihin liittyviä motiiveja (ibid, 66).

Julkisen historiakulttuurin kaltaisella aineellisella, julkisessa tilassa konkreettisesti näkyvällä historiapolitiikalla on suuri vaikutus kansalaisten menneisyyskäsityksiin. Sen voi katsoa vaikuttavan montaa muuta historiapolitiikan muotoa todennäköisemmin myös niihin kansalaisiin, jotka eivät ehkä muuten arkielämässään olisi niin kiinnostuneita menneisyydestä. Torsti asettaakin toistensa vastakohdiksi perinteisen, valikoidun joukon tuottaman akateemisen historiantutkimuksen ja historiakulttuurin, joista jälkimmäinen käsittää hänen mukaansa kaikki yhteiskunnassa elävät ihmiset ja heidän arkipäiväiset kytköksensä menneisyyteen (Torsti 2003, 47.) Myös historioitsijat Jorma Kalela ja Hannu Salmi ovat korostaneet ammattihistorioitsijoiden kannanottojen muodostavan suhteellisen pienen osan yhteiskunnassa käytävästä menneisyyskeskustelusta. Kalela on kritisoinut ammattikuntaansa ajattelusta, jonka mukaan ihmisten menneisyyskäsityksiin vaikuttaisivat ennen kaikkea vain historiasta tehdyt tutkimukset (Kalela 2000,11-12; Salmi 2001, 134.) Koska tutkijat yleisesti sulkevat akateemisen historiantutkimuksen historiakulttuurin tutkimuksen ulkopuolelle (Salmi 2001, 135-137), tehdään niin tässäkin artikkelissa. Esimerkkejä julkisen historiakulttuurin vaikutusvallasta ovat 1990-luvun taitteen Moskovassa käyty keskustelu Feliks Dzeržinskin patsaasta kaupungin keskustan Lubjanka-aukiolla (Etkind 2004, 48) ja Viron vuoden 2007 patsaskiista (Torsti 2008b).

Historiapolitiikan käsitteen määrittely on toisinaan ongelmallista, sillä siihen yhdistetään usein monia muitakin käsitteitä, joita saatetaan käyttää ristiin ja toistensa synonyymeina. Tällainen on esimerkiksi menneisyydenhallinnan käsite. Professori Seppo Hentilän (2005) mukaan menneisyydenhallinnalla (Vergangenheitsbewältigung) tarkoitetaan kykyä käsitellä kansakunnan menneisyyden kipeitä ja kiistanalaisia vaiheita niin, että historiankuva eheytyy. Tämä eroaa selkeästi historiapolitiikasta, jota toteutettaessa taustalla on menneisyydenhallinnan monipuolisuuteen ja avoimuuteen pyrkimisen sijaan aina tietynlainen tarkoitushakuisuus. Esimerkiksi Olga Malinova on esittänyt menneisyyden käytön olevan vain yksi poliittisen aktiivisuuden tapa: hänen mukaansa merkitysten antaminen menneisyydelle ei ole "oikean" politiikan vastinkappale vaan pikemminkin politiikan teon alalaji (Malinova 2018, 87).

Venäläisen kirjallisuuden ja kulttuurihistorian professori Aleksander Etkindin mukaan kokemukset repressioista ovat näkyneet venäläisessä yhteiskunnassa konkreettisten ja mahtipontisten muistomerkkien ja muistojuhlien sijaan pikemminkin epäsuorasti, esimerkiksi 
kirjallisuudessa tai julkisuudessa historiasta käydyissä keskusteluissa. Etkindin mukaan venäläinen yhteiskunta, kulttuuri ja poliittinen elämä ovat luonteiltaan hyvin historiakeskeisiä, mutta neuvostoajan poliittisia repressioita ei ole ikinä käyty läpi sellaisella tavalla, jota tosiasiallinen menneisyydenhallinta vaatisi. Hän pitää syynä yhteiskunnan poliittisen jatkuvuuden ja sosiaalisen konsensuksen puutetta, ja nykyisen yhteiskunnan historiakeskeisyyttä oireena 1990-luvulla keskeneräiseksi jääneestä menneisyyden käsittelystä (Etkind 2004, 42-44, 55.)

\section{Aineisto ja menetelmä}

Aineistoa tarkastellaan laadullisen sisällönanalyysin keinoin. Aineistoa erittelemällä ja siitä eroja ja yhtäläisyyksiä etsimällä pyrin muodostamaan kuvauksen valtiollisesta poliittisten repressioiden historiapolitiikasta. Aineisto koostuu ensisijaisesti Venäjän kahden presidentin, Dmitri Medvedevin ja Vladimir Putinin niistä historiapoliittisesti merkittävistä puheenvuoroista, jotka koskevat poliittisten repressioiden muistamista. Keskityn Vladimir Putinin kolmannella presidenttikaudellaan 30. lokakuuta 2017 pitämiin puheenvuoroihin (Putin 2017a; Putin 2017b) ja hänen joulukuussa 2018 pitämäänsä Aleksandr Solženitsyn -juhlavuoden puheeseen (Putin 2018), ja vertaan niitä Dmitri Medvedevin kahteen vuonna 2009 tekemään historiapoliittiseen kannanottoon (Medvedev 2009a; Medvedev 2009b). Kannanotot on julkaistu venäjäksi ja englanniksi Venäjän presidentin virallisilla kremlin.ru-verkkosivuilla. Puheenvuoroja analysoidessa on tärkeää ottaa huomioon niiden konteksti: Medvedevin ja Putinin repressioita koskevat kannanotot ovat jo sellaisinaan erittäin merkityksellisiä, sillä venäläisessä poliittisessa järjestelmässä presidentti on merkittävä vallankäyttäjä. Tämän vuoksi puheilla voidaan katsoa lähtökohtaisesti olevan muutakin kuin symbolista painoarvoa. Lisäksi on huomioitava, etteivät presidentit vastaa yksin puheistaan. Muiden huippupoliitikkojen lailla myös heidän puheidensa muotoiluun on todennäköisesti osallistunut laaja asiantuntijoiden kokoonpano.

Aikajärjestyksessä ensimmäinen tarkastelemani kannanotto on Dmitri Medvedevin syyskuussa 2009 julkaisema artikkeli "Eteenpäin, Venäjä” (Medvedev 2009a), joka käsitteli hänen uuden talouspainotteisen modernisaatio-ohjelmansa linjavetoja. Medvedev käsitteli artikkelin herättämää yhteiskunnallista keskustelua vielä myöhemmin saman vuoden marraskuussa Yhtenäisen Venäjän puoluekokouksessa ja joulukuussa pitämässään televisiopuheessa. Viimeistään puheen televisiointi mahdollisti artikkelin viestin leviämisen laajemmin kansalaisten tietoisuuteen, ja lisäsi näin ollen sen historiapoliittista merkityksellisyyttä. Toinen Medvedeviltä tarkastelemani kannanotto on hänen poliittisten repressioiden muistopäivänä 30.10.2009 blogissaan pitämänsä videopuhe, joka käsitteli Neuvostoliiton aikaisten poliittisten repressioiden muistamista ja kansakunnan historiatietoisuuden merkityksellisyyttä (Medvedev 2009b). Puhetta ei televisioitu, mutta kannanotto oli jo itsessään poikkeuksellinen ja siksi merkittävä. Esimerkiksi professori Nanci Adler korosti aiemman presidentti Putinin antaneen repressioiden uhreille virallisen tunnustuksensa ainoastaan vuonna 2007 (Adler 2012, 330).

Lisäksi tarkastelen lyhyesti hallituksen vuonna 2015 antamaa säädöstä nro. 1561, joka käsittelee poliittisen sorron uhrien muiston säilyttämiseksi toteutettavia poliittisia linjauksia (Pravitelstvo Rossijskoi federatsii 2015). Tämä on mielestäni perusteltua, sillä Putinin vuoden 2017 poliittisia repressioita koskevat historiapoliittiset kannanotot liittyvät ensisijaisesti tämän säädöksen toimeenpanoon. Vuoden 2017 poliittisten repressioiden muistopäivänä 30.10. hän puhui historian tapahtumien hyväksymisen tärkeydestä kaksi kertaa, joista ensimmäisen kerran presidentin kansalaisyhteiskunta- ja ihmisoikeusneuvostossa, toisen kerran myöhem- 
min samana päivänä ukaasin nro. 487 (Putin 2015a) perusteella luodun Itkumuuri-nimisen muistomerkin avajaisissa (Putin 2017a; Putin 2017b). Tässä yhteydessä viittaan myös Putinin vuonna 2015 ihmisoikeusneuvostossa pitämään puheenvuoroon, jossa hän pohdiskeli kansalaisten ja yleisemminkin venäläisen yhteiskunnan suhtautumista uuteen asetukseen ja menneisyyden tapahtumiin (Putin 2015b).

Aikarajaukseni viimeinen poliittisten repressioiden muistamisen kannalta merkittävä presidentillinen puheenvuoro on Putinin joulukuussa 2018 Aleksandr Solženitsynin satavuotismuistojuhlassa muistomerkin vihkimistilaisuudessa pitämä juhlapuhe, joka käsitteli kirjailijan vaikutusta Venäjän historiaan ja ylipäätään venäläisyyteen (Putin 2018). Puheita analysoitaessa on tärkeää ottaa huomioon niiden konteksti ja kohderyhmä: oletettavasti presidentin ihmisoikeusneuvostossa edistetään asioiden ajamista, ja kannanottojen lähtökohtainen kohderyhmä on rajattu määrä korkean tason poliittisia toimijoita. Poliittisten repressioiden muistopäivän ja Solženitsyn-juhlavuoden puheiden kohderyhmänä ovat oletettavasti kaikki Venäjän kansalaiset, ja niiden tarkoitus on saada kuulijat hiljentymään historian ja sen tapahtumien herättämien ajatusten äärellä.

Presidentillisten kannanottojen lisäksi tarkastelen myös sitä, miten valtiojohtoinen historiapoliittinen toiminta on heijastunut kansalaisjärjestö Memorialin ja Venäjän ortodoksisen kirkon poliittisten repressioiden muistamiseen. Toiminnan tarkastelussa hyödynnän venäläisillä ja ulkomaalaisperäisillä uutissivustoilla vuosina 2013-2018 julkaistuja uutisia. Venäläisistä uutissivustoista ja -toimistoista ovat aiheesta kirjoittaneet muun muassa Fontanka, Vedomosti, Kommersant, Karelia News, Ria Novosti ja TASS. Ulkomaalaisperäisillä uutissivustoilla aiheesta ovat uutisoineet muun muassa Deutsche Welle ja Radio Svoboda. Uutisia lähdeaineistona käytettäessä on luonnollisesti syytä ottaa huomioon uutiskanavan luonne: esimerkiksi TASS ja Ria Novosti ovat valtio-omisteisia uutistoimistoja, joten on oletettavaa että niiden tuottamien uutisten on myös tarvittaessa tuettava poliittisen johdon mielipiteitä. Ottaen huomioon ne ongelmat, joita lehdistönvapauteen yleisesti kohdistuu Venäjällä, on mielestäni hyvä ottaa mukaan tarkasteluun myös ulkomaisia uutistoimijoita, jotka saattavat kertoa samoista asioista painottaen erilaisia näkökulmia ja hyödyntäen erilaisia lähdeaineistoja.

\section{Repressioiden historiapolitiikan vaiheista}

Poliittisten repressioiden historiapolitiikan vaiheet ovat heijastelleet Neuvostoliiton ja sittemmin Venäjän poliittisia suhdanteita. Siinä on ollut vuosikymmenten mittaan havaittavissa useita eri kehityssuuntauksia ja painotuksia, jotka kertovat sekä neuvostoliittolaisen että sittemmin venäläisen yhteiskunnan kehitysvaiheista. Koska sitä ovat olleet luomassa useat sellaiset toimijat, joista kullakin on ollut omat motiivinsa ja näkemyksensä repressiohistorian esittämisestä, ei voida katsoa että Venäjällä olisi ylipäätään ollut olemassa yhtä yksiselitteistä, kollektiivista käsitystä siitä, kuinka repressiohistoriaan tulisi suhtautua ja kuinka sitä tulisi julkisesti muistaa ja käsitellä.

Ensimmäisinä poliittisten repressioiden lähihistoriaa alkoivat tuoda esiin dissidentit, jotka 1950-luvulta alkaen haastoivat julkisesti valtion virallisen näkemyksen Stalinin ajan tapahtumista (Horvath 2005, 7). Huomattavaa oli, että dissidentit esittivät repressioiden pääsyynä olleen yhteiskunnan rakenteet, eivätkä selittäneet niiden toteutumista esimerkiksi Stalinin persoonallisuudenpiirteillä. He pyrkivät tuomaan esille sitä, että esimerkiksi vankileirit olivat Stalinin valtakauden päättymisestä huolimatta yhä osa Neuvostoliiton todellisuutta (ibid, 
18.) Kuuluisia dissidenttejä ovat olleet muun muassa Andrei Saharov, Vladimir Bukovski ja Ljudmila Aleksejeva.

Venäjän valtion aihetta kohtaan herännyt kiinnostus on ollut merkittävää, sillä julkisuudessa sen suhde repressioihin on ollut suhteellisen välttelevä ja varovainen. ${ }^{2}$ Pinnan alla on kuitenkin kytenyt jo vuosikymmeniä ajatus julkisen historiakulttuurin luomisen tarpeellisuudesta. Esimerkiksi ehdotuksia uhreille omistetun julkisen muistomerkin luomiseksi on ollut esillä sekä kommunistisen puolueen pääsihteereiden Nikita Hruštšovin ja Mihail Gorbatšovin että presidentti Boris Jeltsinin hallintokausilla (1953-1964, 1985-1991, 1991-1999) (Sherlock 2016, 11). Gorbatšov nosti esiin muistomerkin rakentamisen tarpeen uudestaan vuonna 2008, jolloin hänen kannanottonsa sai kansainvälisen lehdistön huomion (Anstett 2011).

Alun perin repressiomenneisyyden aiempaa avoimemman käsittelyn mahdollisti 1980-luvun jälkipuoliskoa määritelleen glasnost-periaatteen käyttöönotto. Uudenlainen vapaampi yhteiskunnallinen ilmapiiri mahdollisti sen, että perinteisen kommunistisen puolueen ylläpitämän historiakäsityksen rinnalle julkisuuteen saattoi nousta useita kilpailevia narratiiveja ja näkemyksiä menneisyydestä (Bogumil 2018, 5-7.) Historiapolitiikkaa alkoivat tuolloin tuottaa etenkin neuvostoliittolaisen historiakäsityksen ja sitä myötä neuvostovallan legitimiteetin kyseenalaistanut kansalaisjärjestö Memorial, että myös Venäjän ortodoksinen kirkko, joista jälkimmäinen piti repressioita todisteena Venäjän kansakunnan oikeauskoisuudesta ja poikkeuksellisuudesta (ns. uusmarttyyrit, ks. esim. Rousselet 2013, Christensen 2017). ${ }^{3}$ Sekä Memorial että ortodoksinen kirkko ovat halunneet hyödyntää repressioiden kokemusta Venäjän kansallisen yhtenäisyyden vahvistamiseen: laillisuusperiaatetta, demokratiaa ja ihmisoikeuksia ajavan Memorialin mukaan kipeän historian kollektiivisella työstämisellä olisi ratkaiseva vaikutus sellaisen yhteiskunnallisen muutoksen välineenä,joka kykenisi purkamaan nyky-Venäjän yhteiskuntajärjestelmän autoritääriset rakenteet (Stelms 2007, 112; Bogumil, Moran \& Harrowell 2015, 6-7). Järjestön asema on heikentynyt 2010-luvun aikana, sillä viranomaiset ovat pyrkineet rajoittamaan sen toimintaa monin eri tavoin.

Ortodoksisen kirkon mukaan repressioiden jälkeisen Venäjän kansallinen yhtenäisyys vahvistuu kristillisen anteeksiannon ja unohduksen kautta (Rousselet 2013, 49). Kirkon asema sekä repressioiden historiapolitiikan tekijänä että ylipäänsä yhteiskunnallisena vaikuttajana on kasvanut viime vuosien aikana. Osasyynä tähän lienevät kirkon ja valtion väliset tiiviit suhteet: anteeksiannon ja kansallisen yhtenäisyyden korostaminen vie pois huomiota Putinin hallinnolle kiusallisesta syyllisyyskysymyksestä. Huomionarvoista on myös, ettei ortodoksinen kirkko pidä repressioita yksinomaan neuvostovenäläisenä ilmiönä, vaan osana 1900-luvun laajempaa, ensisijaisesti venäläisiin ja muihin neuvostotasavaltojen ortodokseihin kohdistunutta vainojen sarjaa (Rousselet 2013, 50). Kiinnostava jatkotutkimuksen paikka olisi selvittää, kuinka paljon valtio suoraan ja tosiasiallisesti tukee kirkon tapaa käsitellä repressiohistoriaa, ja missä määrin kyse on vain yleisemmin Putinin 3. kauden hallinnolle tärkeiden uuskonservatiivisten ja nationalististen arvojen edistämisestä (Aitamurto 2019, 47-48, 59). Vaikka tutkimuskirjallisuudessa korostetaan usein edellä mainittujen historiapoliittisten toimijoiden eroavaisuuksia, ovat ne kuitenkin tehneet usein keskinäistä yhteistyötä, jolloin etusijalla on ollut yhtenäinen tavoite muistaa ja kunnioittaa repressioiden uhreja (esimerkiksi yhteisten muistopäivien järjestäminen).

Ymmärtääkseen hallinnon historiapolitiikkaa ja sen päämääriä on ymmärrettävä myös hallinnon mentaliteettia. Vladimir Gelmanin mukaan Venäjän nykyjohtajien sukupolven mielenmaisemaa leimaa usein unelma "hyvästä Neuvostoliitosta", eli valtiojärjestelmästä josta puuttuvat Neuvostoliiton ideologinen ehdottomuus ja taloudelliset ongelmat (Gelman 
2017, 41). 2000-luvun yhteiskunnallinen kehitys oli tarjonnut unelmalle hyvät puitteet: tuolloinen talouskasvu ja yleinen elintason nousu takasivat Kremlille kansalaisten silmissä sen poliittisen legitimiteetin (Sherlock 2015, 13). Poliittisten repressioiden historian uudenlainen julkinen käsittely ja ylipäätään Putinin hallinnon lisääntynyt historian käyttö kertoo siitä, että hallinto joutuu kamppailemaan aiempaa enemmän yhteiskunnallisen vakauden ja oman valta-asemansa säilyttämiseksi. 2000-luvulta periytynyt pitkäaikainen kehitystrendi on pyrkinyt esittämään neuvostomenneisyyden yksiselitteisen positiivisessa valossa. Viime vuosina keskustelua on herättänyt etenkin Josif Stalinin rehabilitointi ja kasvanut kansansuosio (Levada 2016; Levada 2018).

\section{Medvedevin historiapoliittiset kannanotot}

Ensi alkuun valtion historiapoliittinen aktivoituminen näkyi poliittiset repressiot tuomitsevien julkisten kannanottojen yleistymisessä. Syyskuussa 2009 Dmitri Medvedev tuomitsi Eteenpäin, Venäjä-artikkelissaan Neuvostoliiton modernisaation nimissä toteuttamat repressiot. Artikkelissa historia edusti Medvedeville ennen kaikkea mahdollisuutta suunnanmuutokseen ja menneisyydestä oppimiseen. Medvedev halusi modernisoida Venäjän uudenlaisten arvojen ja keinojen avulla, ja perusteli tätä Venäjän kahden suurimman historiassaan läpikäymän modernisaation epäonnistumisilla. Hänen mukaansa Pietari Suuren 1700-luvun alun modernisaation ja myöhemmän Neuvostoliiton modernisaation lopputulemiksi koituivat viime kädessä vain tuho, nöyryytys ja "miljoonien maanmiestemme kuolemat" (Medvedev 2009a.) Tuomitessaan neuvostorepressiot voi Medvedevin mielestäni nähdä samalla tuominneen ne venäläiselle yhteiskunnalle tyypilliset vallankäytön tavat, joihin hän toivoi muutosta, vaikkei tätä suoraan sanonutkaan. Valtiojohtoisen, pakkokeinoin toteutettavan modernisaation sijaan hän halusi kehittää Venäjästä vahvan, vapaan ja vauraan sellaisella demokraattisella tavalla, jossa valtion etua ei asetettaisi yhteiskunnan ja yksilön edun edelle (Medvedev 2009a.)

Thomas Sherlockin mukaan artikkelin tarkoitus oli edistää Medvedevin länsimaistunutta käsitystä moderniudesta ja modernisaatiosta (Sherlock 2016, 5). Mielestäni sitä voi historiapolitiikan näkökulmasta pitää ennen kaikkea sisäpoliittisesti motivoituneena puheenvuorona, jonka avulla Medvedev pyrkii tekemään eroa edeltäjäänsä Putiniin. Toki Medvedevin linjauksia voi pitää myös historiallisena jatkumona niille Neuvostoliiton johtajanvaihdoksille, joissa uusi johtaja pyrki erottautumaan edeltäjästään kehittämällä omia, yleensä mahdollisimman paljon vanhasta radikaalisti erottuvia näkemyksiään.

Poliittisten repressioiden muistopäivänä 30.10.2009 Medvedev käsitteli suoremmin repressioiden muistoa ja kansakunnan historiatietoisuuden merkityksellisyyttä. Hän korosti ensisijaisesti olevansa vakuuttunut siitä, että "kansallisten tragedioiden muisto on yhtä pyhä kuin voittojen muisto". Puhe oli arvoiltaan humaani ja aavistuksen paatoksellinenkin, sillä Medvedev kuvaili repressioiden uhrien kokemuksia tunteita herättävästi ja ilmoitti uskovansa, ettei mikään kansallinen edistys, menestys tai kunnianhimoinen päämäärä voi kehittyä ihmisen kärsimyksen ja menetysten rinnalla. Hän tuomitsi jyrkästi kaikki ne tahot, joiden mukaan jokin "korkeampi kansallinen tavoite" oikeutti repressiot ja niistä johtuneet lukemattomat inhimilliset menetykset. Medvedev myös tuomitsi suoraan yritykset "antaa minkäänlaista oikeutusta niille, jotka tuhosivat kansaamme" (Medvedev 2009b.)

Medvedevin puheessaan kritisoima tapa oikeuttaa repressioita saa tukea tutkimuskirjallisuudesta. Jekaterina Klimenkon mukaan Venäjällä on 2000-luvulla yleistynyt historiapoliittinen trendi, jossa repressiot pyritään rationalisoimaan esittämällä ne historiallisesti 
välttämättömänä, ellei jopa väistämättömänä tapahtumasarjana, jota Neuvostoliitto tarvitsi taloudelliseen modernisaatioonsa ja teollistumiseensa. Tähän liittyy muun muassa tapa esittää Stalin ensisijaisesti "tehokkaana johtajana" (Klimenko 2018, 143.) ${ }^{4}$ Sherlockin mukaan Medvedev oli myös aiemmin samana syksynä tuominnut ne hiljattain uudistetut venäläiset oppikirjat, joissa stalinismia oli käsitelty repressioita rationalisoivasta näkökulmasta (Sherlock 2016, 5). Mielestäni repressioita rationalisoiva puhetapa ja sen herättämä yhteiskunnallinen keskustelu kertoo siitä, että menneisyydenhallinta on Venäjällä yhä keskeneräinen ja vaikea aihe, ja että kyseisillä historian tapahtumilla on yhä välinearvoa Venäjän nykyisessä historiapolitiikassa.

Medvedev korosti etenkin nuoremman sukupolven roolin tärkeyttä repressioiden muistamisessa. Ilman Venäjän historian ristiriitaisuuden ymmärtämistä on mahdotonta ymmärtää monien nyky-Venäjän ongelmien ja vaikeuksien taustoja. Puheessa oli havaittavissa myös isänmaallinen sävy, jossa hän painotti nuorten ihmisten kansalaishengen tärkeyttä, ja kykyä hyväksyä menneisyys sellaisenaan "kypsän kansalaiskulttuurin merkkinä". Repressioiden muiston välittämiseksi tuleville sukupolville, tulisi paitsi jatkaa muiston vaalimista, myös joukkohautojen etsimistä, uhrien henkilöllisyyden tunnistamista ja mahdollista rehabilitointia (Medvedev 2009b.)

Samoihin aikoihin myös silloinen pääministeri Putin tuomitsi Stalinin "massarikokset", ja painotti pakkovallan käytön olevan paitsi moraalisesti väärin, myös ylittämätön este talouden aidolle kehitykselle (Sherlock 2016, 6). Edellä mainitut kannanotot olivat merkittäviä, kun huomioidaan se myönteinen sävy, jolla Stalinista ja ylipäänsä Neuvostoliitosta on venäläisessä julkisuudessa puhuttu. Toisaalta aiemmin mainittu koulujen historianopetuksesta käyty keskustelu sai osakseen uusia sävyjä syksyllä 2010, kun yläkoulujen opetussuunnitelman pakolliseen lukulistaan sisällytettiin lyhennetty versio Aleksandr Solženitsynin teoksesta Vankileirien saaristo. Pääministeri Putin piti tapahtumaa merkittävänä virstanpylväänä ja korosti teoksen merkittävyyttä Venäjälle (RIA Novosti 2010.) Koska koulujen historianopetus on aina jossain määrin politisoitunutta (Torsti 2009a, 62), voinee elettä pitää vähintäänkin symbolisesti merkittävänä.

\section{Säädös 1561}

Paras esimerkki uudenlaisesta valtiojohtoisesta historiapolitiikasta on hallituksen 2015 antama valtioneuvoston säädös nro. 1561, joka käsittelee tulevaisuuden toimenpiteitä ja linjauksia poliittisen sorron uhrien muiston säilyttämiseksi (Pravitelstvo Rossijskoi federatsii 2015). Sitä voi pitää Venäjän valtion virallisen poliittisten repressioiden historiapolitiikan tosiasiallisena avauksena. Säädöksen luomisen mahdollisti Medvedevin vuoden 2010 lopulla tekemä nimitys, kun hän nimitti tunnetun venäläisen liberaali-ajattelija Mihail Fedotovin johtamaan Venäjän presidentin kansalaisyhteiskunta- ja ihmisoikeusneuvostoa. Muun muassa Memorial ja monet muut liberaalia kansalaisyhteiskuntaa edustavat tahot saivat olla mukana osallistumassa ohjelman laatimiseen esimerkiksi historiallisen perspektiivin tarjoajina (Rousselet 2013, 49; Sherlock 2016, 6, 10.)

Lopullisessa muodossaan 2015 hyväksytyn ohjelman tärkeimmäksi tavoitteeksi nimettiin sellaisen yhtenäisen politiikan kehittäminen, joka kaikista tuloksellisimmin palvelisi poliittisten repressioiden uhrien muiston säilyttämistä. Tämä toteutuisi muun muassa luomalla laaja ja kestävä historiakulttuurin verkosto, parantamalla repressioita koskevan tiedon saatavuutta ja saavutettavuutta (esim. sähköisten tietokantojen luominen, arkistoihin pääsyn helpottaminen), 
ja edistämällä koulutusta ja tutkimusta (Pravitelstvo Rossijskoi federatsii 2015, 5-6.) Tähän asti tavoitteista on toteutunut muun muassa Memorialin sähköisen tietokannan laajentuminen loppuvuodesta 2017 (Prava tšeloveka v Rossii 2017).

Repressiohistorian avointa käsittelyä pidettiin edellytyksenä ohjelmassa nimettyjen laajempien yhteiskunnallisten tavoitteiden toteutumiselle. Näitä olivat muun muassa kestävän modernisaation toteuttaminen ja Venäjän kansainvälisen arvovallan lisääminen. Venäläiselle valtiojohtoiselle historiapolitiikalle tyypilliseen tapaan tavoitteiden saavuttamisessa korostettiin isänmaallisuuden ja kansallisen yhtenäisyyden tärkeyttä (Pravitelstvo Rossijskoi federatsii 2015, 1-2.) Näiden hyveiden avulla olisi mahdollista palauttaa sekä Venäjän kansallinen itsekunnioitus, että myös ylpeys kansallisen historian hyvistä ja myönteisistä puolista (Kalih 2011, 5-8).

Vaikka ohjelma näyttäisikin kannustavan historian aiempaa avoimempaan käsittelyyn ja korostavan tätä kautta saavutettavan kansallisen yhtenäisyyden ja uudenlaisen yhteiskunnallisen kehityksen merkitystä, jättää se kuitenkin kiinnostavasti huomiotta kysymyksen syyllisyydestä ja syyllisten tuomitsemisesta (Klimenko 2018, 144). Syyllisyyskysymystä ei ole kyetty käsittelemään venäläisessä julkisuudessa avoimesti ja kattavasti tähänkään päivään mennessä, ja se näyttäisi olevan edelleen aiheena liian kiistanalainen ja arkaluontoinen tullakseen sisällytetyksi sinänsä edistykselliseen poliittiseen ohjelmaan. Tarkasteltaessa Venäjän yhteiskunnallista tilannetta näin useampi vuosi ohjelman hyväksymisen jälkeen ei näkyvissä liene kuvatun laista yhteiskunnallista modernisaatiota. Syynä lienee se, että tällainen modernisaatio vaarantaisi Putinin hallinnon legitimiteetin. Hallinnon pyrkimys legitimiteettinsä säilyttämiseen on ollut nähtävissä Kremlin 2011-2012 vuodenvaihteen aikaisista mielenosoituksista käynnistyneessä, tiukentuneessa hallintatavassa, jota Vladimir Gelman on nimittänyt pelon politiikaksi (Gelman 2017, 37). Sherlockin mukaan ohjelmaan onkin syytä suhtautua ennen kaikkea sellaisena valtion historiapolitiikan välineenä, joka pyrkii vahvistamaan hallinnon legitimiteettiä etenkin korkeasti koulutettujen kansalaisten silmissä. Hänen mukaansa tämän tärkeys on korostunut Venäjän heikentyneen talouskehityksen myötä: autoritaariset valtarakenteet eivät ole enää 2000-luvun tapaan kyenneet oikeuttamaan hallintoaan talouskasvulla ja kansalaisten parantuneella elintasolla (Sherlock 2016,3.) Myös Gelman painottaa Venäjän heikentyneen taloustilanteen osuutta eräänä pelon politiikan juurisyistä (Gelman 2017, 37).

\section{Putin ja repressiohistoria}

Ohjelma poliittisten repressioiden uhrien muiston säilyttämisestä ei ole kuitenkaan pelkkä mielikuvien herättämiseen tarkoitettu silmänkääntötemppu, sillä jo ennen sen virallista hyväksymistä vuonna 2014 oli alettu keskustella uudenlaisen historiakulttuurin luomisesta Moskovaan ja sen lähialueille. ${ }^{5}$ Ortodoksisen kirkon, kansalaisjärjestöjen ja valtion edustajien keskustelujen merkittävin lopputulema oli päätös Moskovaan pystytettävästä repressioiden uhreille omistetusta muistomerkistä (Sherlock 2016, 11.) Muistomerkin luomisprosessissa valtion rooli oli ensisijaisesti koordinoida eri virastojen, kansalaisjärjestöjen ja ortodoksisen kirkon välistä keskustelua ja yhteistyötä. Valtiolla oli olennainen rooli myös muistomerkin rahoittamisessa (suurin osa rakennuskuluista rahoitettiin Moskovan kaupunginhallinnon budjetista). Lisäksi presidentti Putin oli antanut muistomerkin rakennuttamisesta virallisen ukaasin (Putin 2015a). 
Muistomerkki esitettiin pystytettäväksi Moskovan keskusta-aluetta kiertävän Puutarhakehän ja poliittisen dissidentin ja Nobel-palkitun Andrei Saharovin mukaan nimetyn Saharovprospektin yhtymäkohtaan. Syyskuussa 2015 muistomerkistä järjestetyn suunnittelukilpailun voittajaksi julistettiin Venäjän kansantaiteilijan arvonimen saanut kuvanveistäjä Georgi Franguljan. Sekä julkisten että yksityisten toimijoiden yhteisrahoittaman muistomerkin nimeksi tuli "Itkumuuri" (Sherlock 2016, 11.) Kaksi vuotta työstetty muistomerkki on nimensä mukaisesti useiden metrien levyinen ja korkuinen, kaartuva pronssinen seinämä, joka vaikuttaisi koostuvan kokonaan erilaisista, tunnistamattomista ihmishahmoista. Hahmojen tunnistamattomuus symboloi Franguljanin mukaan uhrien anonymiteettiä, ja muistomerkin muoto kuolemaa, joka ei eritellyt tai valikoinut uhrejaan. Franguljanin mukaan muistomerkin sijainti tavallisessa risteyksessä korostaa sitä, että vastaavanlaiset repressiot voisivat tapahtua missä vain. Itkumuuri avattiin virallisesti poliittisten repressioiden uhrien muistopäivänä ja suuren terrorin 80-vuotismuistovuonna 30.10.2017 (MacFarquhar 2017.)

Putin piti kyseisenä päivänä kaksi merkittävää puheenvuoroa, joista ensimmäisen ihmisoikeusneuvostonsa tapaamisessa ja toisen Itkumuurin avajaisissa Saharov-prospektilla. Molemmat puheenvuorot korostivat Itkumuurin avaamisajankohdan symbolisuutta kahdella eri tasolla. Ihmisoikeusneuvostossa Putinin puheenvuoron pääpaino oli kokonaisvaltaisemmin neuvostohistoriassa, jolloin hän kiinnitti erityistä huomiota vuonna 2017 vietettyyn vallankumouksen 100-vuotismuistovuoteen (Putin 2017a). Muistomerkillä Putin taas korosti nimenomaan repressioiden ja niiden uhrien muistoksi yli 25 vuotta vietetyn muistopäivän merkityksellisyyttä (Putin 2017b). Neuvostossa Putin esitti toivomuksensa Itkumuurin tulevan roolin suhteen: hän toivoi muistomerkin pystyttämisen viimeinkin päättävän kansan jakaantumisen, jonka katsoi alkaneen jo vuoden 1917 yhteiskunnallisista muutoksista. Itkumuurin tulisi symboloida tämän hajaannuksen päättymisen lisäksi repressioiden uhrien ja tekijöiden molemminpuolista anteeksiantoa ja Venäjän historian hyväksymistä sellaisena kuin se tosiasiassa on (Putin 2017a.)

Varsinainen avajaispuhe korosti yhtä lailla Venäjän kansan yhdentymistä ja keskinäisen luottamuksen ja vakauden rakentamisen tärkeyttä, sekä erityisesti sitä, ettei menneisyyden muistaminen tarkoita menneisyyden kostamista. Puhe oli selkeästi suuntautunut tulevaisuuteen, sillä Putin painotti anteeksiannon, sisäisen vakauden ja historiakäsitysten yhtenäisyyden tärkeyttä, jotka takaisivat valtion ja yhteiskunnan vahvuuden ja auttaisivat olennaisesti kansakunnan kollektiivisten tavoitteiden saavuttamisessa. Vaikka hän puheessaan tuomitsikin repressiot oikeuttamattomana tragediana ja korosti muistamisen tärkeyttä etenkin Venäjän tulevaisuutta edustavien nuorten keskuudessa, on kuitenkin huomattava, että hän jätti myös tuolloin huomiotta syyllisyyskysymyksen. Tätä hän perusteli vaaralla repressioiden uusiutumisesta: anteeksiannon lisäksi paras keino estää se, olisi keskittyä koston tai rangaistuksien sijaan yhteiskunnan kehittämiseen ja sisältä päin vahvistamiseen. Tätä tukisi kansallisella tasolla omaksuttava selkeä ja yksiselitteinen repressioita koskeva historiakäsitys (Putin 2017b.)

Putin oli puhunut aiemmin historiallisen keskustelun tärkeyden puolesta, mutta ainakaan tässä yhteydessä ei hänen voinut nähdä kannustaneen kansalaisia avoimeen menneisyyskeskusteluun (kuten 2015 ohjelman perusteella olisi pitänyt). Mielestäni ennen kaikkea syyllisyyskysymyksen vaientaminen kertoi siitä, ettei puheen tarkoituksena ollut menneisyydenhallinnan kaltainen historian kipeiden ja kiistanalaisten vaiheiden avoin ja monipuolinen käsittely ainakaan siinä mielessä kuin Hentilä oli sen esittänyt. Toisaalta puhe pyrki ainakin pintapuolisesti venäläisen historiakuvan eheyttämiseen: siinä pyrittiin tietoisesti epäpolitisoimaan repressiohistoriaan liittyviä merkityksiä ja ottamaan aiheeseen etäisyyttä. Keskeisenä 
viestinä oli, ettei nykyhallintoa saisi haastaa, ja että kaikki mahdolliset uudistukset olisi tehtävä tästä näkökulmasta ja maltillisesti. Avajaispuhe kiteytti kenties parhaiten sen, mistä Putinin hallinnon 2010-luvun historiapolitiikassa on kyse: ohjaavana voimana on menneisyyden käytön avulla tapahtuva sisäisen vakauden ja turvallisuuden maksimointi. Tämä kertoo sekä nykyisiä yhteiskuntaoloja että myös tulevaisuutta kohtaan tunnetusta epävarmuudesta.

Itkumuurin rakennuttamista tukenutta Kremliä on kritisoitu avoimesti tekopyhyydestä ja yrityksistä kaunistella nyky-Venäjän poliittista tilannetta, jota yhä usein määrittävät puutteelliset kansalaisoikeudet ja toistuvat ihmisoikeusloukkaukset. Kritisoijia ovat olleet ensisijaisesti entiset poliittiset vangit ja älymystön edustajat, joista monet ajoivat ihmisoikeuksia jo Neuvostoliiton aikana (esim. Vladimir Bukovski ja Ljudmila Aleksejeva). Heidän mukaansa repressiot eivät ole kaukaisia menneisyyden ilmiöitä, sillä myös Venäjän nykyiset poliittiset vangit tarvitsevat apua ja huomiota samaan tapaan kuin neuvostoajan uhrit ansaitsevat muistamista ja kunnioitusta. Kritiikkiä on herättänyt myös hallinnon passiivinen suhtautuminen syyllisyyskysymykseen (Ks. Ponomarev 2017, Radio Svoboda 2017.) Odotettavissa oli, että myös Memorialin suhtautuminen Itkumuuriin olisi suhteellisen skeptistä. Bogumilin mukaan tämä oli väistämätöntä, sillä Venäjän poliittinen tilanne on muuttunut huomattavasti perestroikan ajasta, eikä Itkumuurin yhteiskunnallinen merkityksellisyys ole siis välttämättä sellainen, kuin jotkin perestroikan ajasta lähtien repressioiden uhrien muistamista ajaneet jäsenet olisivat halunneet (Bogumil 2018, 202.)

Toisaalta esimerkiksi Moskovan uudistetun Gulag-museon johtaja Roman Romanov piti Itkumuuria mahdollisena alkuna repressioiden uudenlaiselle muistamiselle, sillä sen luomisen oli mahdollistanut valtion ja kansalaisten yhteistyö (kansalaiset olivat osallistuneet rahalahjoituksilla) (MacFarquhar 2017). Putin puolestaan korosti jo 2015, pian muistomerkin suunnittelukilpailun tulosten julkistamisen jälkeen, juuri kansalaisten osallistumishalukkuuden merkitystä. Hän piti tätä todisteena sekä repressioiden muistamisen ajankohtaisuudesta, että venäläisen yhteiskunnan kehittyneisyydestä ja tulevista kehitysmahdollisuuksista. Kehittyneen yhteiskunnan merkkeinä hän piti kansalaisten arvostavaa suhtautumista historiaan ja aktiivista halua "vaalia yhteistä historiallista muistiamme." (Putin 2015.)

Itkumuurista käyty keskustelu sai vielä lokakuussa 2018 osakseen jälkinäytöksen, kun Moskovan kaupunki pyrki lisäämään Itkumuurin historiapoliittista merkityksellisyyttä kieltämällä kaupungin Solovetsk-kivellä vuosittain järjestetyn poliittisten repressioiden muistopäivän vieton (Koržova \& Muhametšina 2018). Ehdotus jäi tuloksettomaksi, mutta edusti omalta osaltaan pyrkimystä kontrolloida valtion ja sen hallintoelinten ulkopuolista repressioiden historiapolitiikkaa, ja siirtää siitä yhä suurempaa osaa valtion vaikutuspiiriin. Itkumuuri edusti valtion hyväksymää poliittisten repressioiden käsittelytapaa, Solovetsk-kivi puolestaan Memorialille ja 1980-luvun lopulle ja 1990-luvun alulle tyypillisiä liberaaleja arvoja ja yhteiskunnallista epävakautta. Kaupunki oli alkuun vedonnut kiven aluetta ympäröiviin rakennustöihin ja ehdottanut muistopäivää vietettävän Itkumuurilla, mutta Memorial piti ehdotusta hävyttömänä (Koržova \& Muhametšina 2018). Järjestön voimakas reaktio kertoo Solovetsk-kiven historiallisesta merkittävyydestä ja sen olennaisesta roolista muistopäivien vietossa. Itkumuuriin ei voida mitenkään nähdä liittyvän samanlaista symboliikkaa, sillä sen saaman kritiikin lisäksi sen sijainti on muistopäivän vietolle epäsuotuisa: entisen KGB-talon vieressä sijaitseva Solovetsk-kivi kytkeytyy osaksi paitsi Neuvostoliiton historiaa, myös Moskovan paikallishistoriaa.

Seuraavana vuonna 2018 Venäjällä vietettiin presidentti Putinin ukaasin nojalla (Putin 2014) kirjailija, historioitsija ja dissidentti Aleksandr Solženitsynin satavuotismuistoa kun- 
nioittavaa juhlavuotta. Monin eri tavoin ympäri Venäjää näkyneet juhlallisuudet huipentuivat joulukuussa 2018, kun Moskovassa vihittiin käyttöön Solženitsynin muistomerkki. Putinin tilaisuudessa pitämä puhe keskittyi niihin arvoihin, joita hän näki Solženitsynin edustaneen. Näistä arvoista tärkeimpänä erottui isänmaallisuus. Putin korosti Solženitsynin merkittävyyttä "huomattavana maanmiehenämme" ja "Venäjän todellisena isänmaanystävänä", ja mainitsi myös hänen osallistumisestaan "suureen isänmaalliseen sotaan". Lisäksi Putin esitti Solženitsynin isänmaalliset tunteet hänen kirjallisen ja yhteiskunnallisen elämäntyönsä ensisijaisina innoittajina ja hänen ajatustensa täyttyneen yhtä lailla "kivusta isänmaansa puolesta ja rajattomasta rakkaudesta sitä kohtaan". Putin kuvasi myös myönteisellä tavalla hänen rooliaan Venäjän kansan ja Neuvostoliiton totalitaarisen järjestelmän aiheuttamien kärsimysten kuvaajana, mutta painotti ettei Solženitsyn tästä tai edes karkotuksestaan huolimatta sallinut kenenkään puhuvan "pahasti tai epäkunnioittavasti kotimaastaan ja vastusti kaikkia venäläisvastaisuuden ilmaisuja" (Putin 2018).

Kuten Medvedevin vuoden 2009 ja Putinin vuoden 2017 poliittisten repressioiden muistopäivien kannanottoja, leimasi myös Putinin Solženitsyn-puhetta menneisyydestä oppimisen tärkeys. Putin korosti, kuinka Solženitsynin mukaan tulevaa kohti siirtyminen ei onnistu "ilman maan menneisyyden ymmärtämistä", ja hänen pyrkimyksiään Venäjän kehittämiseen, jotta muun muassa poliittisten repressioiden kaltaiset tapahtumat eivät enää toistuisi (Putin 2018). Koska Putin korosti Solženitsynin henkisen perinnön olevan yhä hyvin ajankohtainen niin Venäjällä kuin muuallakin maailmassa, vaikutti siltä kuin Solženitsynistä ja hänen isänmaallisista ajatuksistaan ja toiminnastaan olisi tehty kuulijoille esimerkki, jonka jäljittelyyn olisi ihailtavaa ja suotavaa pyrkiä. Myös arvot olivat puheessa voimakkaasti läsnä samaan tapaan kuin Medvedevin vuoden 2009 poliittisten repressioiden muistopäivän kannanotossa, vaikka Medvedev painottikin enemmän yleisinhimillisiä arvoja ja vähemmässä määrin isänmaallisuutta. Solženitsyn-puhe oli luonnollisesti henkilökeskeisempi kuin aiemmat presidentilliset kannanotot, mutta yhtä kaikki esimerkki valtiotason pyrkimyksistä käyttää repressioiden muistoa isänmaallisuuden ja yhteiskunnallisen vakauden edistämiseen.

Koska poliittisten repressioiden julkinen historiakulttuuri on luonteeltaan jakautunutta, ei repressiohistoriasta voida katsoa olevan olemassa yhteistä historiallista muistia niin kuin Putin sen esitti. Maallista, ortodoksista ja Medvedevin ja Putinin presidentinhallintojen poliittisten repressioiden historiakulttuuria yhdistääkin tällä hetkellä lähinnä jaettu näkemys siitä, että repressiot olivat historiallinen tosiasia, ja että niiden nimissä tehdyt teot olivat moraalisesti ehdottoman tuomittavia. Itkumuuri symboloi kuitenkin sellaisen uudenlaisen historiapolitiikan alkua, jossa valtiolla olisi aiempaa aktiivisempi rooli. Merkkejä aiempaa valtiojohtoisemmasta historiapolitiikasta ovat tähän asti olleet historiakulttuurin keskittäminen pieniltä paikkakunnilta ja paikalliskeskuksista suurempiin kaupunkeihin (ennen kaikkea Moskovaan), ja se, että valtio on ottanut enenevässä määrin haltuunsa aiemmin Memorialille kuuluneita poliittisten repressioiden historiapolitiikan osa-alueita.

\section{Historiapolitiikan nykyisyyden kontrollointi}

Selkein esimerkki valtiojohtoisen historiapolitiikan yrityksistä kontrolloida itsestään riippumatonta repressiohistorian käsittelyä on 2000-luvun lopulla alkanut kansalaisjärjestö Memorialin toiminnan vaikeuttaminen. Taustalla ovat olleet Venäjän valtion edustajat ja Kremliä tukevat aktivistit. Järjestön tiloihin tehtyjen yllätystarkastusten ja aineistojen takavarikointien lisäksi (Ks. esim. Fontanka 2013; 2016, Puškarskaja 2015) ${ }^{6}$ laaja-alaisimpia ja 
kuuluisimpia esimerkkejä tästä ovat olleet toistuvat yritykset leimata järjestö "ulkomaiseksi agentiksi”. Tämän taustalla on vuonna 2012 säädetty laki "ulkomaisista agenteista", jonka mukaan kaikkien ulkomaista rahoitusta saavien, valtiosta ja hallinnosta riippumattomien ja poliittista toimintaa harjoittavien kansalaisjärjestöjen tulee rekisteröityä erilliseen rekisteriin (Ofitsialnyi internet-portal pravovoi informatsii 2012). Laki on vaikeuttanut Memorialin toimintaa, sillä sen on muun muassa raportoitava toiminnastaan jatkuvasti viranomaisille ja hoidettava sitä vastaan kohdistettuja oikeustoimia. Tämä kaikki syö resursseja ja on siten pois järjestön varsinaisesta työstä (Mikkonen 2017.) Esimerkiksi Deutsche Welle uutisoi lain voivan olennaisesti vaikeuttaa järjestön valtion viranomaisten ja hallinnon kanssa tekemää yhteistyötä (esimerkiksi pääsyä arkistoihin, ks. Sherwin 2016). ${ }^{7}$ Vuonna 2014 Venäjän oikeusministeriö pyysi korkeimmalta oikeudelta koko järjestön lakkautusta (esim. Muhametšina 2014; Višnevetskaja 2014). Samankaltainen uhkaus kohdistettiin myös Andrei Saharovin mukaan nimettyyn moskovalaiseen Saharov-keskukseen, joka Memorialin lailla kartoittaa Venäjän ihmisoikeustilannetta ja ylläpitää monin eri tavoin repressioiden muistoa (ironista on, että Itkumuurin sijainniksi valittiin myöhemmin nimenomaan Moskovan Saharov-katu) (Slade 2017, 45).

Memorialin vaikeudet ovat heijastuneet myös sille tärkeiden repressiohistorian paikkojen vaiheisiin. Esimerkiksi Arkangelin alueeseen kuuluvien Solovetskin luostarisaarten vankileirihistorian historiakulttuuri on muuttunut kuluneiden kymmenen vuoden aikana vastaamaan paremmin ortodoksisen kirkon näkemystä repressioiden historiasta. Ortodoksisen kirkon ja valtion läheisen yhteistyön vuoksi kehityssuunta kertoo mielestäni siitä, että saarten vankileirihistoria pyritään esittämään tavalla, jonka myös valtio voi tarvittaessa hyväksyä.

Kehityksen voi katsoa alkaneen Venäjän kansalaiskamarin vuonna 2008 Vladimir Putinille lähettämästä kirjeestä, jossa Solovetskille vaadittiin sen historiallisen ja hengellisen merkityksellisyyden perusteella suojellun alueen erityisstatusta (Bogumil 2018, 32-33). Samana vuonna duuma luovutti kulttuuriministeriön suositusten perusteella suurimman osan Solovetskin alueista ortodoksisen kirkon hallinnoinnin alaisiksi. Kirkon näkökulmasta toimenpide edusti heidän laillisten maidensa ja niiden käyttövaltuuksien palauttamista, mutta esimerkiksi Solovetskin vankileirihistoriaa kuvannut museo ja lukuisat Venäjän tiedeyhteisön edustajat näkivät tämän uhkana Solovetskin vankileirihistorian monipuolisuuden säilymiselle. Lukuisat ortodoksisesta historiakäsityksestä irtisanoutuvat tahot vetosivat Putiniin avoimessa kirjeessä, jossa painottivat alueen vankileirimenneisyyden monimuotoisuuden huomioinnin tärkeyttä. Kirje jäi kuitenkin tuloksettomaksi (Dorman 2010, 343.)

Seuraavana vuonna 2009 aiemmin riippumattoman Solovetsk-museon johtajuus ja hallinnointi siirrettiin ortodoksiselle kirkolle, perusteluna saarten kulttuuriperinnön hallinnoinnin sujuvoittaminen. Tämän myötä Solovetskin vankileirimenneisyydestä on tullut enenevässä määrin väline ortodoksisen historiapolitiikan edistämiseksi. Vankileirihistoriaa käsittelevien näyttelyjen sisältömuutosten lisäksi on alettu myös irtisanoa sellaista museon henkilökuntaa, jonka menneisyyskäsitykset poikkeavat ortodoksisen kirkon edustajien näkemyksistä. Lisäksi aiempia yhteyksiä Memorialin kanssa yhteistyössä toteutettuun historiapolitiikkaan on tarkoituksellisesti heikennetty, todennäköisimmin siksi että Memorialin läsnäolon nähdään politisoivan vankileirihistorian käsittelyä epätoivotulla tavalla (Bogumil 2018, 33, 65.)

Historiapoliittiset kontrollointiyritykset ovat näkyneet myös Karjalan tasavallan Sandarmoh-joukkohaudalla, jossa kesällä 2018 tehtyjen kaivausten tuloksena löytyneiden ruumiiden jäänteitä väitettiin suomalaisten jatkosodan aikana tappamien puna-armeijan sotilaiden jäänteiksi. On epäselvää, ketkä käytännössä suorittivat Venäjän sotahistorial- 
lisen seuran tilaamat kaivaukset. Varmaa kuitenkin on, että seuralla on läheiset yhteydet presidentti Vladimir Putiniin, jonka käskystä seura perustettiin vuonna 2012, ja sitä myötä Venäjän korkeimpaan hallintoon. Kaivausten tulosten kyseenalaisessa esittämisessä on ollut kyse selkeästi pidempiaikaisesta poliittisesti motivoituneesta prosessista. Tapahtumien voi nähdä alkaneen vuodesta 2016, jolloin historioitsijat Sergei Veriginin ja Juri Kilin esittivät hypoteesin siitä, että Sandarmohiin voisi olla haudattuna mahdollisesti jopa useita tuhansia suomalaisten teloittamia neuvostovankeja. Useat venäläiset ja suomalaiset asiantuntijat ovat kyseenalaistaneet sekä väitteen että Venäjän sotahistoriallisen seuran tilaamien kaivausten todelliset tarkoitusperät, ja kaivausten tulosten esittämisen puolueettomuuden: paikalle ei ole päästetty median edustajia eikä ulkopuolisia tarkkailijoita, eikä niistä ole myöskään tiedotettu mediassa. Kysymyksiä saattaa herättää myös Sergei Veriginin asema Karjalan sotahistoriallisen seuran puheenjohtajana. Historioitsija Irina Takalan mukaan kyse on poliittisesti motivoituneesta toiminnasta, jonka tavoite on häivyttää Memorialin osuus ratkaiseva osuus joukkohaudan löytämisessä ja alueen muistamisperinteen käynnistämisessä. Tämän puolesta puhuisi ainakin se, että Veriginin ja Kilinin väitteen kyseenalaistanut, Sandarmohin löytänyt historioitsija ja Karjalan tasavallan Memorial-osaston puheenjohtaja Juri Dmitriev on ollut pidätettynä useaan otteeseen vuodesta 2016 alkaen (Beljantšikov 2018.) Useat historioitsijat ja teloitettujen omaiset vetosivat avoimessa kirjeessä muun muassa Venäjän kulttuuriministeriöön, Karjalan ja Karhumäen aluehallintoihin ja Venäjän sotahistorialliseen seuraan kaivausten lopettamiseksi, mutta kirje jäi tuloksettomaksi (Mimmijeva 2018). Historioitsija Nikita Sokolovin mukaan viime vuosien toiminnassa on viime kädessä ollut kyse sellaisesta valtiollisesta historiapolitiikasta, jonka avulla pyritään kaunistelemaan neuvostomenneisyyttä ja kohdistamaan suuren yleisön huomio suomalaisiin sotilaisiin. Hänen mukaansa Sandarmohia yritetään muuttaa Stalinin aikaisten vainojen joukkoteloituspaikasta enemmän tyypilliseksi suuren isänmaallisen sodan muistomerkiksi. Tätä tukee havainto siitä, etteivät paikallisviranomaiset ole osallistuneet useisiin vuosiin Memorialin Sandarmohissa järjestämiin Neuvostoliiton poliittisten repressioiden uhrien muistopäiviin (Beljantšikov 2018.) Tämän kaltainen toiminta vahvistaa näkemystä siitä, että Putinin hallinto suhtautuu syyllisyyskysymykseen välttelevästi ja pyrkii häivyttämään Venäjän valtion näkökulmasta epäsuotuisaa historiapolitiikkaa. ${ }^{8}$

Yleisemmällä tasolla repressioiden historiakulttuurin kontrolloinnista kertoo kansainvälisestikin huomiota saanut Permin alueella sijainneen entisöidyn vankileirin Perm-36:n tapaus, jossa uudenlaisen historiapolitikoinnin taustalla ovat olleet ortodoksisen kirkon ja valtionelinten sijasta paikallishallinnon edustajat. Ulkomaisten agenttien laki vaikutti osaltaan myös siihen, että Venäjän ainoan, alkuperäisessä kunnossaan yhä olemassa olevan vankileirimuseon Perm-36:n hallinnointioikeudet siirrettiin kulttuuriministeriölle vuonna 2013 (Slade 2017, 45). Leirin rakennukset entisöineet ja niitä ylläpitäneet paikallisen kansalaisjärjestön jäsenet irtisanottiin asemistaan. Todennäköisesti päätöksen taustalla oli Putinin vuonna 2012 tapahtunut paluu presidentiksi, ja hänen kolmannen kautensa alun aiheuttamat hallinnolliset muutokset Permin kuvernementin johdossa (Gessen 2018, 104.) Päätös museon hallinnon muutoksesta perustui myös taloudellisille syille. Valtiosta riippumattomalla museolla ei olisi ollut läheskään samoja mahdollisuuksia saada kipeästi tarvitsemaansa taloudellista tukea (etenkään kun museota oli alettu enenevässä määrin leimata Venäjä-vastaiseksi sen käymän avoimen menneisyyskeskustelun takia). Johtajuuden vaihtuessa myös museon sisältö muuttui. Nykyään se keskittyy repressioiden sijaan itse vankileirijärjestelmän esittelyyn ja esimerkiksi sen taloudellisiin saavutuksiin. On paljonpuhuvaa, että tässä yhteydessä sisällöistä on 
poistettu viittaukset Staliniin. Neuvostoliiton ajan jälkeistä vankileiriturismia analysoineen Sladen mukaan Perm-36:n ja Moskovan Gulag-museon eriävät kohtalot kertovat siitä, että tämänhetkisessä venäläisessä poliittisten repressioiden historiapolitiikassa ei ole kyse niinkään menneisyyden suoranaisista kieltämisyrityksistä, vaan pikemminkin pyrkimyksestä kasvattaa valtion roolia historiapoliittisena toimijana ja repressioiden muistamisen määrittelijänä (Slade 2017, 45-46.) Yhtä kaikki voidaan kuitenkin katsoa, että Perm-36:n lakkauttamisella pyrittiin kääntämään huomiota pois itse repressioista ja valtion osallisuudesta niihin. Paikan säilyttäminen ja toiminnan jatkaminen kertoo kuitenkin siitä, että sen historiapoliittinen merkittävyys tiedostetaan hyvin myös hallinnon ylemmillä tasoilla.

\section{Historiapoliittisten linjausten pitkäaikaiset vaikutukset vielä auki}

Historiapolitiikan tutkiminen on tärkeää, sillä merkitysten antaminen menneisyydelle on kaiken aikaa elävä prosessi joka muokkaa käsityksiämme nykyisyydestä ja ennen kaikkea odotuksiamme tulevaisuudesta. Tämän saattoi havaita myös Putinin ja Medvedevin repressiohistoriaa koskevissa kannanotoissa. Niiden perusteella poliittisten repressioiden historiaa voi pitää sellaisena selkeänä historiapolitiikan välineenä, jonka käytön taustalla on pyrkimys tärkeinä pidettyjen poliittisten ja yhteiskunnallisten tarkoitusten saavuttamiseen. Valtiojohtoista historiapoliittista toimintaa on käytetty myös valtiosta itsestään riippumattoman historiapolitiikan ja historiakulttuurin kontrolloimiseen.

Molempien presidenttien kannanotoissa repressiohistoriaa pyrittiin hyödyntämään muun muassa oman hallinnon legitimiteetin tukemiseen, tärkeinä pidettyjen arvojen edistämiseen ja välineenä Venäjän yhteiskunnan kehittämiseen. Repressiohistorian ymmärtämisen ja hyväksymisen tärkeyttä perusteltiin ensisijaisesti sillä, että menneisyyden ymmärtämistä pidettiin yhteiskunnallisen kehityksen edellytyksenä. Tämän vuoksi kannanotoissa vedottiin erityisesti nuorempien, Venäjän tulevaisuudesta vastaavien sukupolvien rooliin repressiohistorian muiston ylläpitäjinä. Repressiohistorian muistamisen avulla presidentit pyrkivät edistämään myös yksilöidympiä yhteiskunnallisia tavoitteita. Näistä Medvedevin puheissa korostuivat Venäjän modernisaation ja poliittisten repressioiden historiantutkimuksen edistäminen, Putinin puheissa Venäjän yhteiskunnan sisäisen vakauden ja kansallisen yhtenäisyyden edistäminen. Historiapolitiikan motiivien näkökulmasta kannanotoissa korostuivat sisäpoliittiset motiivit ja universaalin hyvän motiivit: sekä Putin että Medvedev pyrkivät korostamaan sitä historiallista katkosta, jonka halusivat näyttää erottavan toisistaan nykyhetkeä ja neuvostoajan hallintoa. Universaalin hyvän motiiveista selkeimpänä, molempien presidenttien kannanottoja yhdistävänä tekijänä erottui väkivallan tuomitseminen. Tärkeinä pidetyistä arvoista useimmin nousi esille isänmaallisuus ja se, kuinka tärkeinä sekä Putin että Medvedev pitivät pyrkimystä olla isänmaallisuuttaan aktiivisesti toteuttava kansalainen.

Kannanottojen huomattavin ero oli poliittisten repressioiden muistopäivien puheissa näkynyt eriävä suhtautuminen syyllisyyskysymykseen: Medvedev otti siihen suoraan kantaa ja tuomitsi repressioiden toteuttajat, vaikkei tuonutkaan ilmi sitä, että neuvostoajan repressioista vastasi pohjimmiltaan itse neuvostovaltio. Putin sivusi syyllisyyden teemaa epäsuoremmin, ja käsitteli sitä ensisijaisesti anteeksiannon kautta. Hänen puheenvuoronsa ei antanut ymmärtää, että syyllisyyskysymystä tultaisiin lähivuosinakaan käsittelemään julkisuudessa aiempaa yksityiskohtaisemmin. Tämän, ja Memorialin historiakulttuurin kontrollointipyrkimysten, vuoksi on Venäjän menneisyydenhallinta tällä hetkellä vain näennäistä. Tosiasialliseen menneisyydenhallintaan olennaisesti kuuluvan avoimen keskustelun tulevaisuutta voi tällä 
hetkellä vain arvailla.

Tarkasteltaessa valtiojohtoisen historiapoliittisen toiminnan heijastumista kansalaisjärjestö Memorialin ja Venäjän ortodoksisen kirkon poliittisten repressioiden tuottamiin historiapolitiikkoihin, voidaan tulla siihen tulokseen, että Venäjän valtionhallinto pyrkii toiminnallaan kontrolloimaan ja rajoittamaan etenkin Memorialin poliittisista repressioista tuottamaa historiakulttuuria. Tälle on monia todennäköisiä syitä. Laajemmassa mittakaavassa kyse on valtiosta riippumattomien kansalaisjärjestöjen toiminnan yleisluonteisesta kontrolloinnista, jonka voidaan katsoa yleistyneen 2000-luvun lopulta alkaen. Toisaalta etenkin Putinin hallinto saattaa pitää epätoivottavana Memorialin historiapolitiikan liberaaleja arvoja ja järjestön pyrkimystä edistää syyllisyyskysymyksen avointa käsittelyä. Kehityssuunta on erittäin kiinnostava etenkin, kun huomioidaan valtion sallineen Memorialin yksittäisten edustajien osallistua säädöksen 1561 suunnitteluun ja toteuttamiseen. Toistaiseksi on vaikea arvioida, onko hallinnon suopeus repressiohistorian avoimelle käsittelylle ja Memorialin osallisuudelle silkkaa fasadia, jonka avulla pyritään Venäjän politiikalle tyypilliseen mielikuvien luomiseen ja niillä pelaamiseen. Repressiohistorian näennäisen avoin käsittely on ristiriidassa valtionhallinnon autoritaaristuneiden otteiden ja samanaikaisesti heikentyneiden kansalaisoikeuksien kanssa. Tämä herättää kysymyksiä valtionhallinnon motiiveista. Neuvostoajan poliittisista repressioista näyttäisi olevan tarkoitus tehdä vihdoin osa virallista, valtion tunnustamaa historianarratiivia, mutta valtion omilla säännöillä. Toistaiseksi kontrollointipyrkimyksissä näyttäisi olevan räikeähkön ja suoran menneisyyden vääristelyn sijaan kyse pikemminkin hienovaraisista yrityksistä sivuuttaa ja poistaa valtion näkökulmasta epäedullisen historiakulttuurin jälkiä.

Aidosti avointa ja julkista repressiohistorian käsittelyä rajoittanee ennen kaikkea se, ettei Venäjän valtio ole halukas myöntämään neuvostovaltion syyllisyyttä ja vastuullisuutta repressioiden syntymisestä, laajenemisesta ja ylläpidosta. Koska Venäjän valtio ei ole koskaan tosiasiallisesti irtisanoutunut neuvostohallinnosta, ei sille ole ollut edullista korostaa repressioiden ja neuvostohallinnon välistä suoraa yhteyttä. Poliittisten repressioiden historiakulttuurin hajanaisuuden pääsyynä voi mielestäni pitää kollektiivisen historiakäsityksen puutetta, joka puolestaan on seurausta venäläisen yhteiskunnan sisäisestä hajanaisuudesta.

Koska valtio on toiminut tämän historiapolitiikan kentällä suhteessa lyhyen aikaa, eivät sen historiapoliittisten linjausten pitkäaikaiset ja tosiasialliset vaikutukset ole vielä kunnolla nähtävissä. Jatkossa olisikin ehdottoman tärkeää tutkia esimerkiksi sitä, missä määrin säädökselle 1561 asetetut tavoitteet on saavutettu. Ohjelman olemassaolo on todiste siitä välinearvosta, joka repressiohistorialla ja historialla ylipäänsä on nyky-Venäjän hallinnolle.

Vaikka kehityssuuntaus onkin jatkunut samanlaisena noin vuodesta 2008 alkaen, ei Venäjän tulevaisuudesta voida tehdä vielä varmoja johtopäätöksiä. Pyrkimykset repressioiden historiapolitiikan hallinnoimiseksi näyttävät yhä keskeneräisiltä. Tällä hetkellä repressiohistoriasta näytetään yritettävän (monen muun kansallisen historian osa-alueen lailla) tehdä välinettä vallankäytölle, joka pyrkii yhteiskunnan vakauden ja sisäisen yhtenäisyyden ylläpitoon ja sitä myötä Putinin hallinnon ja nykyisen eliitin legitimiteetin vahvistamiseen. Tilanteen kehitykseen vaikuttaa suuresti se, mihin suuntaan venäläinen yhteiskunta tulee lähivuosina kehittymään. Voimistuuko autoritäärinen kehitys, vai saavatko pitkään jatkuneet kansalaisprotestit aikaan tosiasiallisen yhteiskunnallisen muutoksen? 
1 Valtiojohtoisella historiapolitiikalla saattaa olla tulevaisuudessa aiempaa suurempi vaikutus kansalaisten historiatietoisuuteen: esimerkiksi VTsIOM:n valtiollisen tutkimuslaitoksen mukaan: 2017 toteutetun kyselytutkimuksen mukaan lähes puolet (47\%) 18-24-vuotiaista nuorista ei ollut koskaan kuullut neuvostoajan repressioista. Katso: https://wciom.ru/index.php?id=236\&uid=9344.

2 Esimerkiksi vuonna 2007 suuren terrorin 70-vuotismuistovuonna Vladimir Putin osallistui ensimmäistä kertaa Butovon joukkohaudoilla pidettyyn muistojumalanpalvelukseen, jossa tuomitsi neuvostoajan poliittiset repressiot. Tuolloin pahennusta herätti kuitenkin hänen osallistumattomuutensa Moskovan Solovetsk-kivellä pidettyyn muistoseremoniaan, jossa neuvostoajan vainoista selviytyneet kertoivat kokemuksistaan. Aiempina vuosina Putin ei ollut osallistunut lokakuun lopun poliittisten repressioiden muistopäivinä järjestettyihin tilaisuuksiin, vaan viettänyt sen sijaan KGB:n vuosipäivää tuttaviensa kanssa (Adler 2012, 330).

3 Uusmarttyyreilla tarkoitetaan Neuvostoliiton hajoamisen jälkeen kanonisoituja marttyyreja.

4 Näkemys repressioista modernisaationa korostuu todennäköisesti etenkin sellaisilla sijainneiltaan syrjäisillä alueilla, joille vankileirit merkitsivät ensimmäistä askelta vakiintuneen asutuksen synnylle ja kylien ja kaupunkien muodostumiselle (Bogumil 2018, 190).

5 Uudenlaisen historiakulttuurin luomisen tavoitteisiin sisältyi muun muassa Moskovan Gulag-museon laajentaminen ja uudistaminen, ja Moskovan keskustan ja lähiseudun repressioiden historian kannalta merkityksellisten paikkojen kunnostamista ja uudistamista (Sherlock 2016, 11).

6 Memorialin tarkastukset ovat jatkuneet myös vuoden 2019 puolella. (Radio Svoboda 2019).

7 Deutsche Wellen toiminta on herättänyt viime vuosina paljon keskustelua Venäjän poliittisissa elimissä: sitä on syytetty muun muassa Venäjää loukkaavan materiaalin levittämisestä, ja sen kyky noudattaa Venäjän lainsäädäntöä on haluttu asettaa tarkkailun alaiseksi. Tämä saattaa johtaa Deutsche Wellen toimiluvan kieltämiseen Venäjän alueella. Katso: https://tass.ru/politika/5333049, https://www.gazeta.ru/social/2018/06/29/11820133.shtml

8 Sandarmohin tapaus on syksyllä 2019 yhä edelleen ajankohtainen ja historiapolitiikan näkökulmasta merkittävä, sillä aiheesta ja sen ympärillä käytävästä keskustelusta ilmestyi hiljattain Sandarmohin arvoitus-niminen kirjanen. Kirjan pääasiallinen kirjoittaja on Sergei Verigin (Podgornyi 2019.) (*Artikkelin kirjoitushetkellä marraskuussa 2019 kirjanen on ilmestynyt sekä suomeksi että venäjäksi). Aiemmin samana vuonna myös Karhumäen paikallismuseon johtaja ja sotahistoriallisen seuran kaivausten tulokset kyseenalaistanut Sergei Koltyrin pidätettiin ja tuomittiin yhdeksäksi vuodeksi vankeuteen (Gunkel 2019).

\section{Lähteet}

Adler, Nanci (2012), Reconciliation with - or Rehabilitation of the Soviet Past. - Memory Studies 5:3, 327-338. https://doi.org/10.1177\%2F1750698012443889

Aitamurto, Kaarina (2019), Uuden vuosituhannen sinfonia? Ortodoksinen kirkko Venäjän politiikassa. - Uskonto ja maailmanpolitiikka. Toim. Sini Paukkunen, Heikki Pesonen, Tuula Sakaranaho. Tallinna: Gaudeamus, 42-61.

Anstett, Elisabeth (2011), Memory of Political Repressions in Post-Soviet Russia: The Example of the Gulag. The Online Encyclopedia of Mass Violence. 13.9.2011. http://www.sciencespo.fr/ mass-violence-war-massacre-resistance/en/document/memory-political-repression-post-sovietrussia-example-gulag (tarkistettu 14.11.2019).

Beljantšikov, Jevgeni (2018), Podmena pamjati v Sandarmohe natšinajutsja somnitelnye raskopki, kotorye pomogut zabyt o repressijah. Karelia News. 22.8.2018. https://www.karelia.news/news/2134045/ podmena-pamati-v-sandarmohe-nacinautsa-somnitelnye-raskopki-kotorye-pomogut-zabyt-o- 
repressiah (tarkistettu 15.11.2019).

Bogumil, Zuzanna, Moran, Dominique \& Harrowell, Eleanor (2015), Sacred or Secular? 'Memorial', the Russian Orthodox Church, and the Contested Commemoration of Soviet Repressions. - EuropeAsia Studies 67:9, 1416-1444. https://doi.org/10.1080/09668136.2015.1085962

Bogumil, Zuzanna (2018), Gulag Memories: The Rediscovery and Commemoration of Russia's Repressive Past. New York: Berghahn Books.

Christensen, Karin Hyldal (2017), The Making of The New Russian Martyrs of Russia: Soviet Repression in Orthodox Memory. London: Routledge.

Dorman, Veronika (2010), Ot Solovkov do Butovo: Russkaja Pravoslavnaja Tserkov I Pamjat o Sovetskih Repressijah v Postsovetskoi Rossii. - Laboratorium no. 2, 327-347.

Etkind, Alexander (2004), Hard and Soft in Cultural Memory: Political Mourning in Russia and Germany. - Grey Room no. 16, 36-59. https://doi.org/10.1162/1526381041887439

Fontanka (2013), V "Memoriale" uže vtoraja proverka za dvoe sutok. 22.3.2013. <https://m.fontanka. ru/2013/03/22/083/> (tarkistettu 18.11.2019).

Fontanka (2016), Dlja proverki na status inoagenta "Memorial" sobral stopku dokumentov vysotoi potšti v tšetyre metra, 7.9.2016. $<$ https://m.fontanka.ru/2016/09/07/025/> (tarkistettu 18.11.2019).

Gazeta (2018), $<<$ Perešla vsjo granitsy $>>$ DW sdali Roskomnadzoru. 29.6.2018. <https://www.gazeta. $\mathrm{ru} / \mathrm{social} / 2018 / 06 / 29 / 11820133$.shtml $>$ (tarkistettu 18.11.2019).

Gelman, Vladimir (2017), Venäjä ja pelon politiikka. - Idäntutkimus 24:4, 37-50.

Gessen, Masha (2018), Never Remember: Searching for Stalin's Gulag in Putin's Russia. New York: Columbia Global Reports.

Gunkel, Jelena (2019), Karelski istorik Sergei Koltyrin osužden po obvineniju v pedofilii. Deutsche Welle. 27.5.2019. http://www.dw.com/ru/карельский-историк-сергей-колтырин-осужден-пообвинению-в-педофилии/a-48913229 (tarkistettu 15.11.2019).

Hentilä Seppo (2005), Löytyykö totuus komissioista? Historiantutkimus ja totuuskomissiot. Esitelmä Suomalaisen Tiedeakatemian yleisistunnossa Säätytalolla. 12.9.2005. <http://www.mv.helsinki.fi/ home/shentila/Totuus.htm> (tarkistettu 15.11.2019).

Horvath, Robert (2005), The Legacy of Soviet Dissent: Dissidents, Democratisation and Radical Nationalism in Russia. London: Routledge.

Jakobson, Michael (2015), Origins of the gulag: the Soviet prison camp system, 1917-1934. Lexington: The University Press of Kentucky.

Kalela, Jorma (2000) Historiantutkimus ja historia. Helsinki: Gaudeamus.

Kalih, Aleksander (2011), Gody terrora: Kniga pamjati žertv polititšeskih repressi. Tšast šestaja, tom 3. Perm: Tipografija Kuptsa Tarasova.

Klimenko, Jekaterina (2018), The Politics of Oblivion and the Practices of Remembrance: Repression, Collective Memory and Nation Building in Post-Soviet Russia. - Historical Memory of Central and East European Communism. Ed. Agnieszka Mrozik \& Stanislav Holubec. New York: Routledge, 141-162.

Koržova, Darja \& Muhametšina, Jelena (2018), $<<$ Memorial $>>$ obvinil vlasti Mockvy v sryve aktsii pamjati žertv repressi. Vedomosti. 19.10.2018. https://www.vedomosti.ru/politics/ articles/2018/10/19/784183-memorial (tarkistettu 15.11.2019).

Levada-tsentr (2016), Figura Stalina v obštšestvennom mhehii Rossii. 25.3.2016. $<$ https://www.levada. $\mathrm{ru} / 2016 / 03 / 25 /$ figura-stalina-v-obshhestvennom-mnenii-rossii/> (tarkistettu 3.2.2020).

Levada-tsentr (2018), Stalin v obštšestvennom mnenii. 10.4.2018. <https://www.levada. $\mathrm{ru} / 2018 / 04 / 10 / 17896 />$ (tarkistettu 3.2.2020).

MacFarquhar, Neil (2017), Critics Scoff as Kremlin Erects Monument to the Repressed. New York Times. 30.10.2017. https://www.nytimes.com/2017/10/30/world/europe/russia-soviet-repressionmonument.html (tarkistettu 21.11.2019).

Malinova, Olga (2018), Constructing the "Usable Past": the Evolution of the Official Historical Narrative in Post-Soviet Russia. - Cultural and Political Imaginaries in Putin's Russia. Ed. Niklas Bernsand \& Barbara Törnquist-Plewa. Amsterdam: Brill, 85-104. https://doi.org/10.1163/9789004366671_006

Medvedev, Dmitri (2009a), Rossija, vperjod! Ofitsialnye setevye resursy prezidenta Rossii. 10.9.2009. $\mathrm{http} / / / \mathrm{kremlin} . r u /$ events/president/news/5413\#sel=15:8:WfW,16:36:ffe (tarkistettu 1.2.2020).

Medvedev, Dmitri (2009b), Pamjat o natsionalnyh tragedijah tak že svjaštšenna, kak pamjat o pobedah. Ofitsialnye setevye resursy prezidenta Rossii. 30.10.2009. http://kremlin.ru/events/president/ news/5862 (tarkistettu 1.2.2020). 
Mikkonen, Erkka (2017), Venäjä tukahduttaa kansalaisyhteiskuntaa. Yle Uutiset. 5.8.2017. https://yle. fi/uutiset/3-9751079 (tarkistettu 15.11.2019).

Mimmijeva Olga (2018), Rodstvenniki rasstreljannyh trebujut otmenit raskopki v urotšištše Sandarmoh. Karelia News. 26.8.2018. https://www.karelia.news/news/2136902/rodstvenniki-rasstrelannyhtrebuut-otmenit-raskopki-v-urocise-sandarmoh (tarkistettu 1.2.2020).

Muhametšina, Jelena (2014), Minjust prosit verhovnyi sud likvidirovat obštšestvo $<<$ Memorial $>>$. Vedomosti. 12.10.2014. https://www.vedomosti.ru/politics/articles/2014/10/13/memorialnayalikvidaciya (tarkistettu 15.11.2019).

Ofitsialnyi internet-portal pravovoi informatsii (2012), Federalnyi zakon no. 121-F3. 23.7.2012. $<$ http://publication.pravo.gov.ru/Document/View/0001201207230003?index $=1 \&$ rangeSize $=1>$ (tarkistettu 15.11.2019).

Podgornyi, Sergei (2019), V Finljandii vyšla kniga o zagadkah urotšištša Sandarmoh. Karelia News. 16.7.2019. https://www.karelia.news/news/2454220/v-finlandii-vysla-kniga-o-zagadkah-urocisasandarmoh (tarkistettu 15.11.2019).

Ponomarev, Ljov (2017), Predlagat obštšestvu prostit prestuplenija gosudarstva protiv tšelovetšnosti ne imeet prava nikto. Eho Moskvy, 15.12.2017. https://echo.msk.ru/blog/lev_ponomarev/2111374echo/ (tarkistettu 15.11.2019).

Prava tšeloveka v Rossij (2017), Reportaž i foto HRO.org o prezentatsij novogo izdanija bazy "Memoriala" o zertvah gosterrora v SSSR. 6.12.2017. <https:/hro.org/node/26888> (tarkistettu 15.11.2019).

Pravitelstvo Rossijskoi federatsii (2015), Rasporjaženie no 1561, Kontseptsija gosudarstvennoi politiki po uvekovetšeniju pamjati žertv polititšeskih repressi. 15.8.2015. <http://static.government.ru/ media/files/AR59E5d7yB9LddoPH2RSlhQpSCQDERdP.pdf> (tarkistettu 15.11.2019).

Puškarskaja, Anna (2015), Minjust obvinil "Memorial" v podryve konstitutsionnogo stroja. Kommersant. 9.11.2015. https://www.kommersant.ru/doc/2850410 (tarkistettu 15.11.2015).

Putin, Vladimir (2014), Ukaz prezidenta Rossiiskoi federatsii, no. 474. Ofitsialnye setevye resursy prezidenta Rossii. 27.6.2014. <http://www.kremlin.ru/acts/bank/38618> (tarkistettu 3.2.2020).

Putin, Vladimir (2015a), Ukaz prezidenta Rossiiskoi federatsii, no. 487. Ofitsialnye setevye resursy prezidenta Rossii. 30.9.2015. <http://kremlin.ru/acts/bank/40063> (tarkistettu 15.11.2019).

Putin, Vladimir (2015b), Zasedanie Soveta po razvitiju graždanskogo obštšestva i pravam tšeloveka. Ofitsialnye setevye resursy prezidenta Rossii. 1.10.2015. http://kremlin.ru/events/councils/bycouncil/18/50411 (tarkistettu 15.11.2019).

Putin, Vladimir (2017), Zasedanie Soveta po razvitiju graždanskogo obštšestva i pravam tšeloveka. Ofitsialnye setevye resursy prezidenta Rossii. 30.10.2017. http://kremlin.ru/events/councils/bycouncil/18/55947 (tarkistettu 15.11.2019).

Putin, Vladimir (2017), Otkrytie memoriala pamjati žertv polititšeskih repressi «Stena skorbi». Ofitsialnye setevye resursy prezidenta Rossii. 30.10.2017. http://kremlin.ru/events/president/news/55948 (tarkistettu 15.11.2019).

Putin, Vladimir (2018), V Moskve otkryt pamjatnik Aleksandru Solženitsynu. Ofitsialnye setevye resursy prezidenta Rossii. 11.12.2018. http://kremlin.ru/events/president/news/59371 (tarkistettu 3.2.2020).

Radio Svoboda (2017), Sovetskie dissidenty protiv ustanovki memoriala "Stena skorbi". 30.10.2017. $<$ https://www.svoboda.org/a/28823404.html $>$ (tarkistettu 15.11.2019).

Radio Svoboda (2019), Minjust proverjajet tsentr "Memorial" po zakonu ob "inostrannyh agentah", 14.1.2019. <https://www.svoboda.org/a/29709107.html> (tarkistettu 15.11.2019).

RIA Novosti (2010), Putin nazval "znakovym" izdanie školnoi versii "Arhipelaga GULAGa" 26.10.2010. <https://ria.ru/20101026/289570932.html> (tarkistettu 3.2.2020).

Rousselet, Kathy (2013), The Russian Orthodox Church and Reconciliation with the Soviet Past. - History, Memory and Politics in Central and Eastern Europe. Memory Games. Ed. Georges Mink \& Laure Neumayer. New York: Palgrave Macmillan, 39-53. https://doi.org/10.1057/9781137302052_3

Salmi, Hannu (2001), Menneisyyskokemuksista hyödykkeisiin - historiakulttuurin muodot. - Jokapäiväinen historia. Toim. Jorma Kalela \& Ilari Lindroos. Helsinki: Kirjakas/Tallprint, 134-149.

Sherlock, Thomas (2016), Russian politics and the Soviet past: Reassessing Stalin and Stalinism under Vladimir Putin. - Communist and Post-Communist Studies 49:1, 45-59. https://doi.org/10.1016/j. postcomstud.2016.01.001

Sherwin, Emily (2016), Russian NGO Memorial to fight 'foreign agent' label in Russia. Deutsche Welle. 5.10.2016. https://www.dw.com/en/russian-ngo-memorial-to-fight-foreign-agent-label-in- 
russia/a-35965436 (tarkistettu 15.11.2019).

Slade, Gavin (2017), Remembering and Forgetting the Gulag: Prison Tourism in the Post-Soviet Region. - The Palgrave Handbook of Prison Tourism. Ed. Jacqueline Wilson, Sarah Hodgkinson, Justin Piché \& Kevin Walby. London: Palgrave MacMillan, 37-54.

Stelms, Georgi (2007), Memorial ja Gulagin muisto. - Venäjän ihmisoikeusliike. Toim. Juri Dzibladze, Anna Sevortjan \& Airi Leppänen. Helsinki: Palmenia, 112-118.

TASS (2019), Zaharova prizvala Sovfed i Gosdumu dat otsenku propagandistkoi dejatelnosti Deutsche Welle. 28.6.2019. <https://tass.ru/politika/5333049> (tarkistettu 18.11.2019).

Torsti Pilvi (2003), Divergent Stories, Convergent Attitudes: A Study on the Presence of History, History Textbooks and the Thinking of Youth in Post-war Bosnia and Herzegovina. Helsinki: Kustannus Oy Taifuuni.

Torsti, Pilvi (2008a), Historiapolitiikkaa tutkimaan: historian poliittisen käytön typologian kehittelyä. - Kasvatus \& aika 2:2, 61-71.

Torsti, Pilvi (2008b), Why do History Politics Matter? The Case of the Estonian Bronze Soldier. The Cold War and the Politics of History. Toim. Juhani Aunesluoma \& Pauli Kettunen. Helsinki: Edita Publishing, 19-35.

Ulturgaševa, Olga (2015), Nasledie GULAGa v sovremennoi povsednevnosti. - Laboratorium 7:1, $15-25$.

Vedomosti (2015), Sozdavšaja muzei istorii repressi organizatsija "Perm-36" budet likvidirovana. 3.3.2015. <https://www.vedomosti.ru/politics/news/2015/03/03/sozdavshaya-muzei-istoriirepressii-organizatsiya-perm-36-budet-likvidirovana $>$ (tarkistettu 15.11.2019).

Višnevetskaja, Julija (2014), Isk minjusta k "Memorialu": projavlenie formalizma ili kampanija davlenija. Deutsche Welle. 13.11.2014. http://www.dw.com/ru/иск-минюста-к-мемориалу-проявлениеформализма-или-кампания-давления/a-18060493 (tarkistettu 15.11.2019).

Volk, Christian (2009), Stalinism, Memory and Commemoration: Russia's dealing with the past. - The New School Psychology Bulletin 6:2, 50-58.

Volnoje istoritseškoje obštšestvo (2017), Kakoje prošloje nužno buduštšemu Rossii. <https://komitetgi.ru/service/\%D0\%A1\%D0\%B1\%D0\%BE\%D1\%80\%D0\%BA\%D0\%B0.pdf > (tarkistettu 21.11.2019).

VTsIOM no 3781, Repressii XX veka: Pamjat o blizkih. 5.10.2018. <https://wciom.ru/index. php?id=236\&uid=9344> (tarkistettu 18.11.2019).

Wood, Elizabeth (2011), Performing Memory: Vladimir Putin and the Celebration of WWII in Russia. - The Soviet and Post-Soviet Review 38:2, 172-200. https://doi.org/10.1163/187633211X591175 